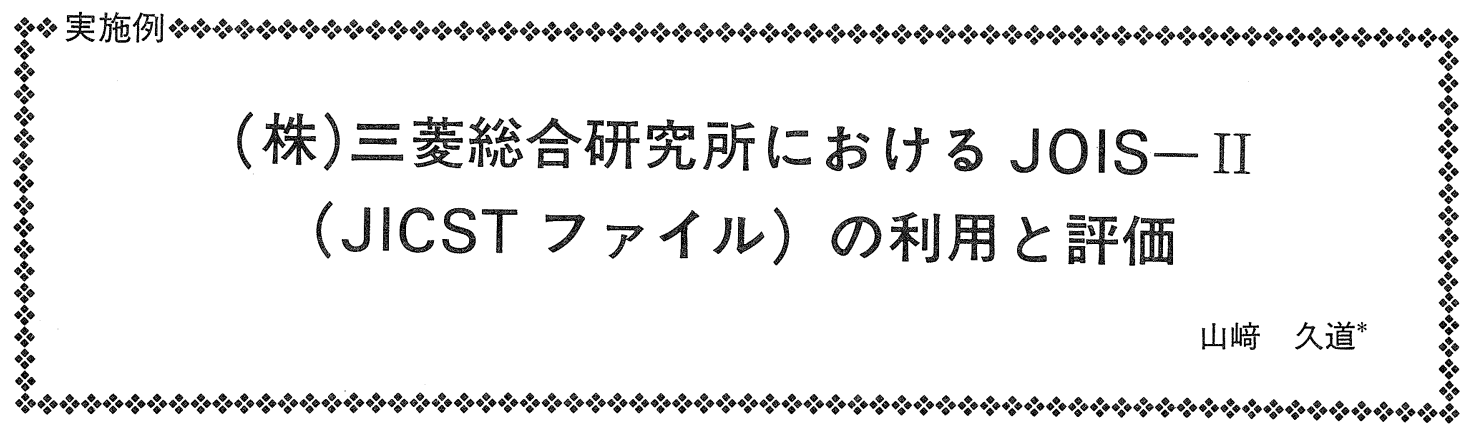

〔抄 録〕三菱総合研究所における，JOIS－II に対する利用者の評価・要望を紹介する。 その内容は, (1)一次・二次検索機能は共に満足すべき水準にあり，特に二次検索（制限検 索）はJOISならではのユニークなもので利用価値が高い，(2)検索補助機能（LOGON， 質問登録など）については，改善の余地がある，(3) JICST シソーラスは便利だが, オンラ イン検索での利用も考慮に入れた編成（コード化など）にしてほしい，などである。また 外部オンライン情報検索システムの利用が当社における研究調査プロセスにおいて，どの ような位置づけと機能を有しているかにも言及した。

1. 研究開発プロセスとオンライン情報検 索

\title{
1.1 オンライン検索利用の背景
}

当社は, 顧客の委託を受けて, 調査研究を行う コントラクト・リサーチ・ファーム, いわゆる「シ ンクタンク」である。近年, 研究プロジェクトの 遂行に当たって，オンライン検索を活用するケー スが目立って増えてきた。

まずオンライン情報検索が，プロジェクトの調 查研究プロセスの中に, どのように組み込まれて いるかを説明しょう（第 1 図）。

オンライン情報検索を利用するのは, 大きく分 けて, (イ)予備調査/プロポーザル作成段階と(口)本調 査に掞ける情報の収集段階の二つである。この二 つの段階では, 情報検索を行ら目的がやや異なる。 (イ)に沶いては，これからあるテーマで調査を実施 するといった場合，そのテーマについてどれくら いの量の情報が存在し, そのらちのどのくらいが 現実にアクセス可能かのメドをつけることが目標 となる。これにより実施しようとする調査プロ

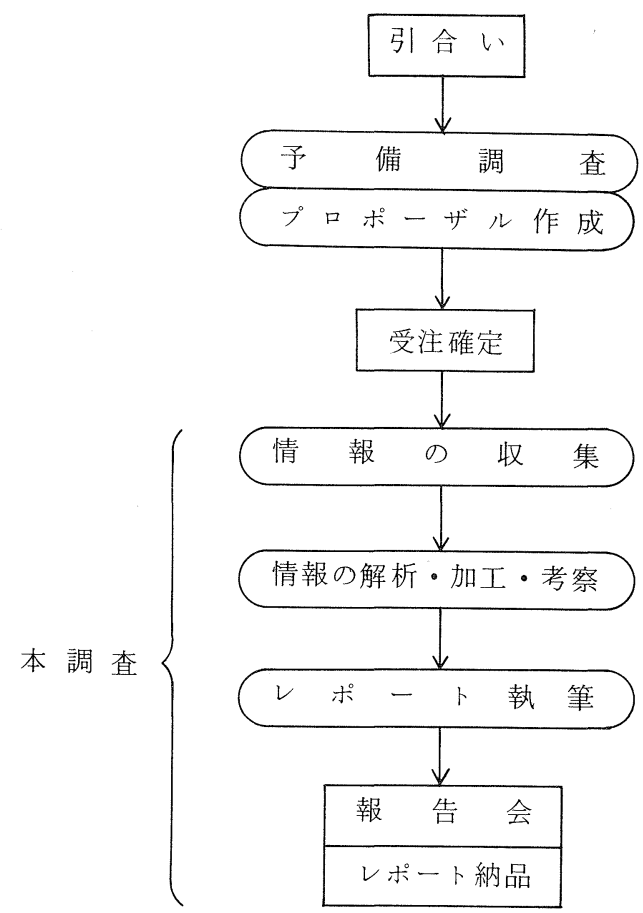

第 1 図 研究プロジェクト遂行のプロセス

*やまざきひさみち 侏三菱総合研究所情報管理部 主任研究員 
ジェクトの情報収集の難易がある程度推定でき， 情報収集のコストを見積もることもできる。

\section{2 利用プロセス}

次に利用の仕組みを情報部門（当社では情報管 理部）の役割を中心に，やや詳しく述べる。その 扣扣よその流れは次のと扣りである。

（1）プロジェクト担当者（研究部門）による情 報管理部への説明

ここでは，調査の内容，目的，㸚らいといった ことが説明され，質疑応答が繰り返される。情報 管理部の基本姿勢として，プロジェクト全体の目 的内容を切り離して，情報収集や検索だけを単独 で請け負う場合は余りない。検索のみの単独請負 では，研究者を満足させる結果を得るのが容易で はないからである。例えば，全く同じ検索テーマ であっても, 予備調査段階と本報告執筆段階では, 目的が明確に異なってくる。前者では，前述した ように特定分野での情報の量やアヴェイラビリ ティが問題になるし，後者では，情報の内容その ものの詳細が求められるからである。

（2）情報管理部による情報収集案の提示

(1)を受けて，そのプロジェクトに最適な情報収 集方法のポートフォリオを示す。社内に存在する 一次資料へのアクセス, 冊子体の二次資料の活用, 外部専門情報機関の利用，オンライン情報検索な ぞがその内容となる。したがって，オンライン情 報検索は，幾つかある情報収集方法のうらの一つ のオプションとして位置づけられている。最近で はオンライン検索が, 最も有効かつ強力な手法と なってきた。ただ，実際上，研究調査自体は，幾 つもの情報收集方法を併用するのが普通である。

(3) 検索戦略の作成

(2)に扮いて，オンライン検索を行らことにした 場合は，よりブレーク・ダウンした検索案行案を 作成する。これには, システムの選択(DIALOG, JOIS など)，ファイルやキーワードの選定が含京 れる。ファイル選択は, 最も難しいステップの一 つで，例光ば，経済分析に関するテーマでも，シ ステム，モデル，シミュレーションなど手法にか
かわるものの場合は，科学技術情報データベース と考えられている JICSTファイルやNTISにア クセス寸ることも必要である。キーワードについ ては, 研究者側であらかじめ幾つか選んできても らい,それを情報管理部サイドで,ドキュメンテー ション的な立場から評価し, 最適な再現率や適合 率を得られるように取捨ないし追加して検索式の 形にする。

(4) 端末機上での検索オペレーション

最近は熟練したューザが増えてきたので，ュー ザ自身が行うことも多い。そうでない場合は，情 報管理部担当者とユーザがターミナルの前に並ん で座り, 実際の操作は, その都度ユーザと協議し ながら情報管理部担当者が行う。といらのは，検 索式をいくらきちんと立てても出てくる文献の量 や質は全く未知であり，システム側のメッセージ を見ながら両者が相談して対応する方がバランス のとれたサーチを行觉るからである。換言すれば, オンライン検索のメリットとして会話性を即時性 と同様に重視してゆこうといらわけである。

（5）原報供給

アウトプットされた抄録，書誌情報はとれだけ で用が足りる場合もあるが，原報を見たいとの希 望が出る場合も多い。原報調達も, 情報管理部の 重要な機能の一つである。オンラインシステムに 出現する文献の原報が 1 か所で保管されている ケース（例：JICSTファイル) はよいが，その他 の場合は, DIALORDER など海外の原報供給機 関から調達するか, あるいは根気よく電話などで 国内の図書館や書店に問い合わせるなどして探す しかない。日本は, 図書館に颃ける蓄積の水準も, 書店のサービスも国際的にみて決して低いとは言 えない。今後は, こうした既存の原報供給部門が， オンラインによるネットワークを通じて検索サー ビスと密接かつ効率的に結合することが望まれ る。

（6）評価・反省

特に, コスト・パフォーマンスの面から検索を 評価する。これは, 次回の検索の重要な参考にな る。 


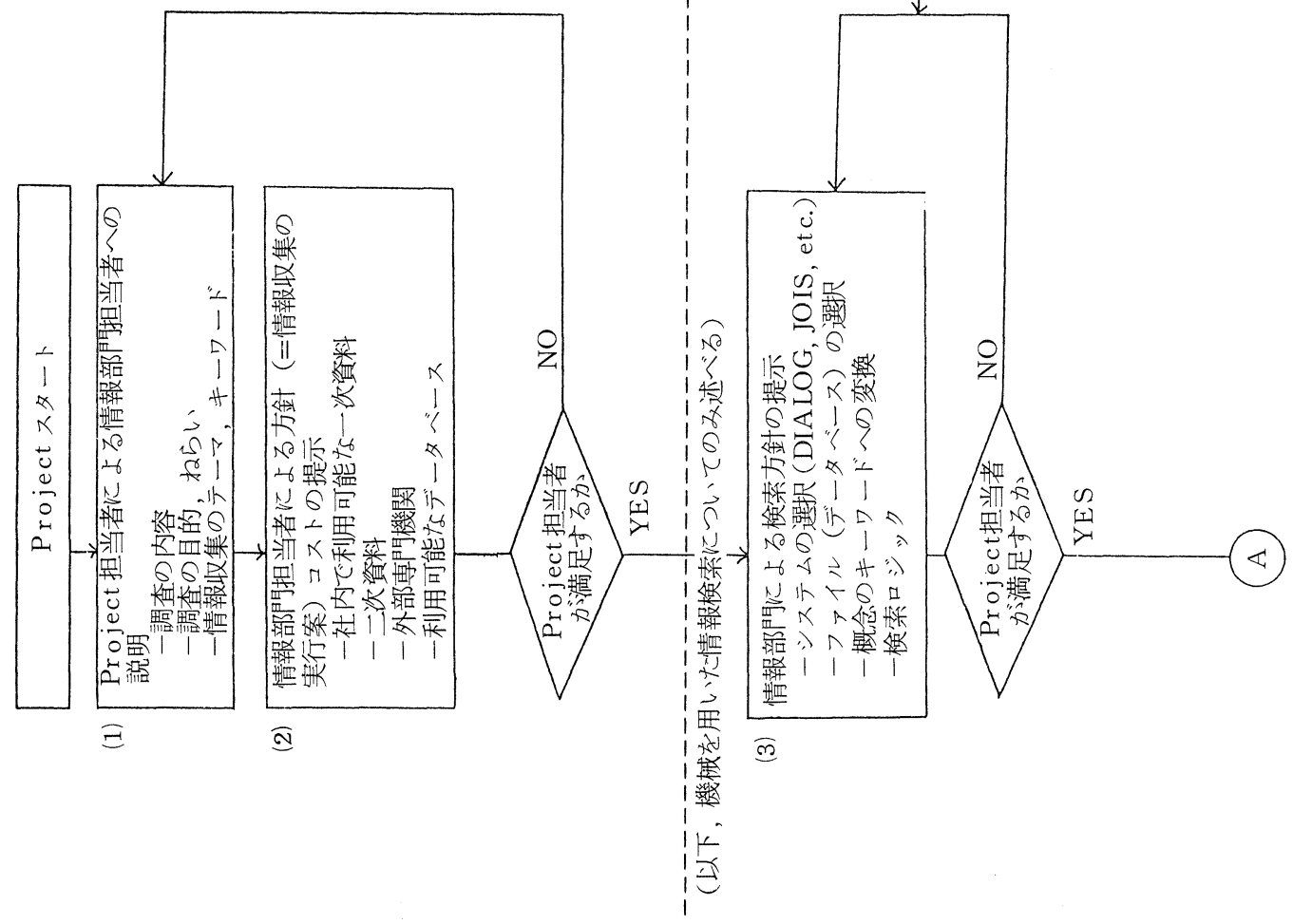

$\infty$

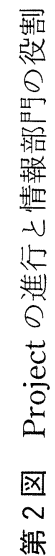
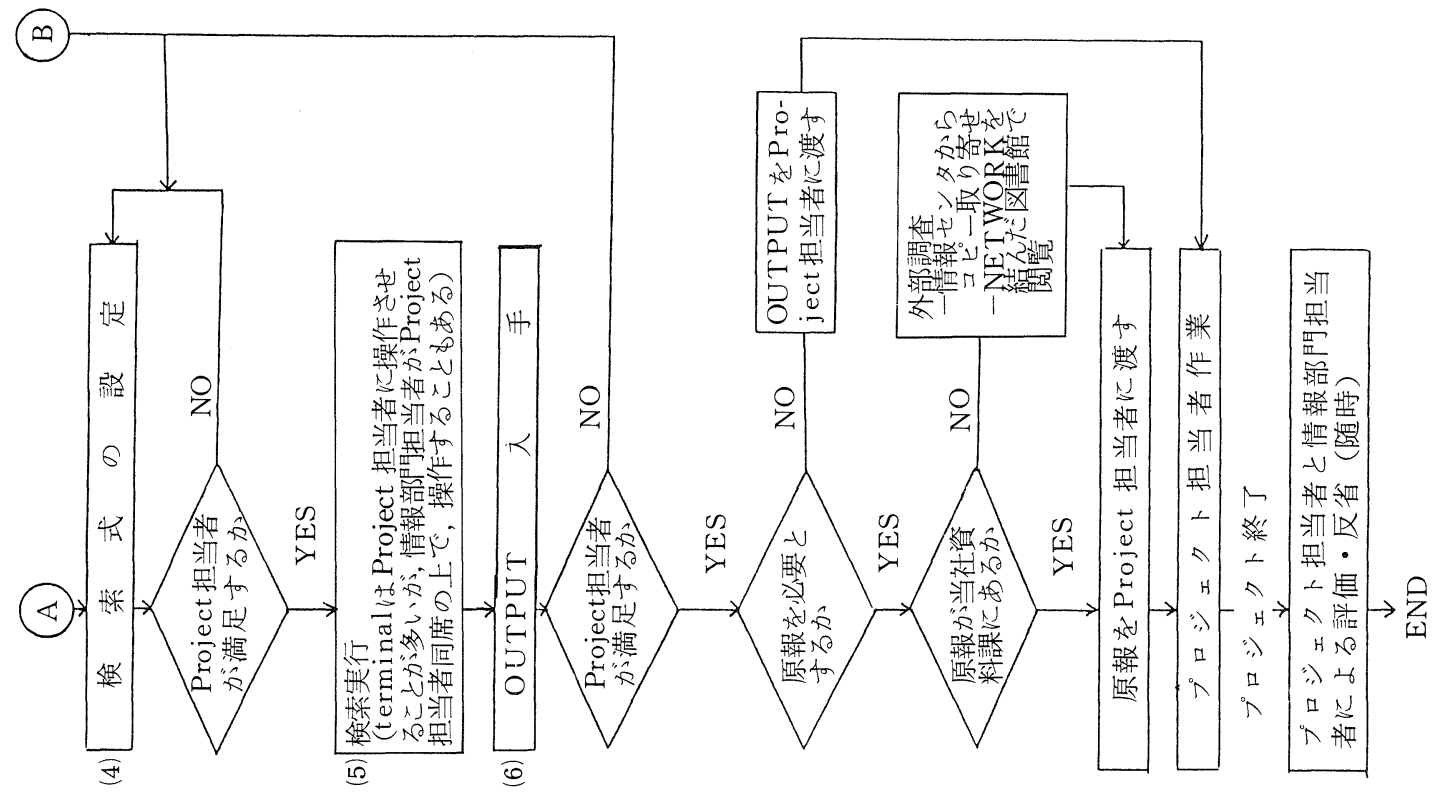
以上述ベたステップを図式化すれば，第 2 図の と执りである。

\section{JOIS の利用実態}

当社に括ける JOIS の 4 半期別利用件数を, 第 3 図に示す。な利用ファイルは初期にはSSIE も少しあったが，臣とんどが JICST ファイルで ある。54年10月以前は, 特定回線端末機を共同利 用していた時代で，このころは余り利用されてい なかった。ところが，54年10月に公衆回線端末機

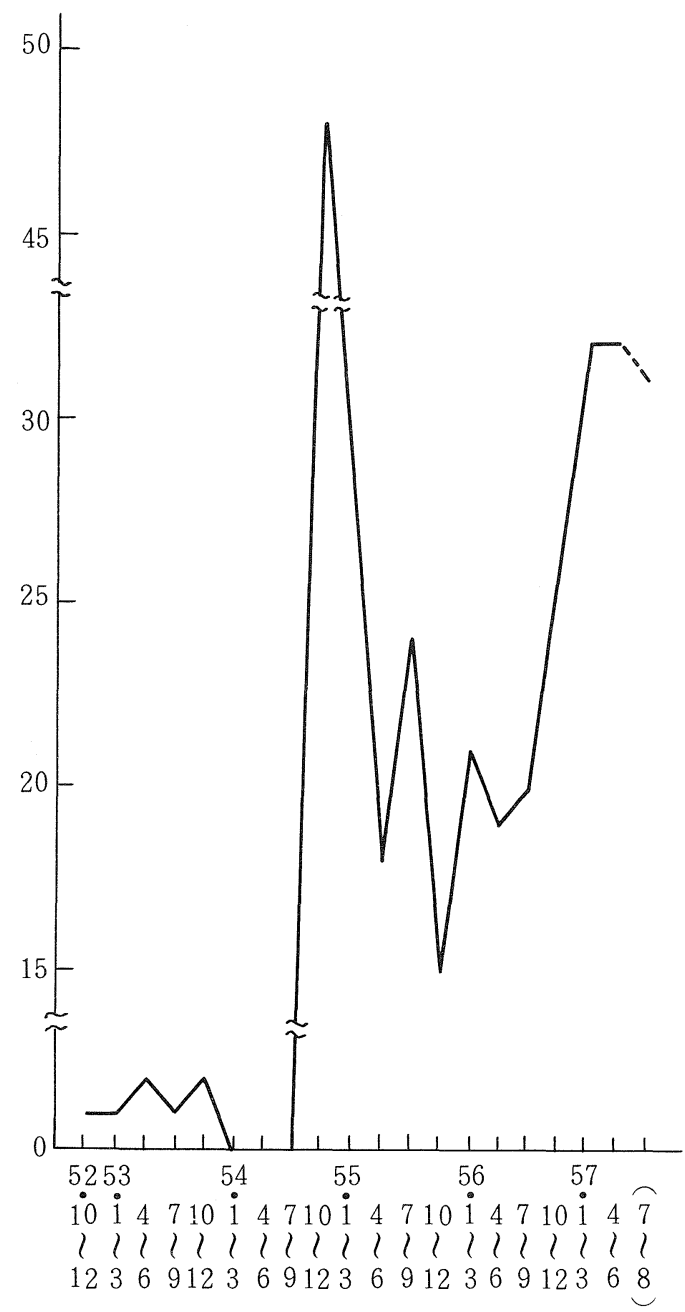

第 3 図 JOIS の利用件数
を導入すると，利用が爆発的に伸び，特に最初の 3 か月間は，当社で導入した最初のオンライン情 報検索システムといらこともあって非常によく使 われた。

この公衆回線端末機導入後の急速な普及には, 実は，特定回線時代の経験が大きくモノを言った のであって，細々ながらも利用を続けて蓄積して 得たものが，一気に開花した感があった。その後 利用は漸減し，55年 DIALOGなども始まり， JICST ファイルに抄録の付いていない JOIS-I は決定的に不利な状況に陷った。

あたかも，この JOIS一Iの利用低迷時にこの JOIS一IIがオープンしたのである。その効果はま ことに目覚ましく，JOISへの見直し気運が一気 に高交り，特に邦文抄録のオンライン出力は圧倒 的な人気を集めて，現在に至っている。

\section{JOIS-II に対する評価と要望}

JOIS一IIは, JICST が JOIS-I, JOIS一Kの 経験をもとに非常に力を入れて開発したものだけ に, JOIS一Iに比べると格段に使いやすく，有効 なシステムになっている。最大のメリットは，恐 らく，漢字仮名混じり文による抄録の付いたレ コードを公衆回線経由で得られるようになったと いらことであろらが，その他の点についても細か く見てゆくと、いろいろな工夫が込められて和り， DIALOG をしのぐと思わ机る部分もある。

当社では, 前述したように, 情報管理部の指導 の下に，エンドューザ自身に端末機を操作させる ようになってきて拈り，JOIS一II もその例外では ない。この際,「JOIS入門」というタイトルの茶 色表紙の手引書が，マニュアルの内容をうまく抜 粋しているので, これから JOIS-IIを操作しよ らとするユーザに 1 冊ずつ渡して, 読んでもらっ ている。その扔かげで，もら既に，研究部門で10 人内外の人たちが JOIS一IIを一応使いこなせる ようになっている。

今回，本稿を扮引き受けするに当たって，JOIS 一IIに関するユーザの評価がまだ余り発表されて 
いないようなので，社内の JOIS を自分でたたけ る人たちにヒアリングして，いろいろ意見を聴い てみた。以下にその内容を，筆者の意見・見解を 含めて項目ごとに整理して紹介する（な掞，前章 で述べたように，当社の場合は JOIS 利用の添涪 100\%が JICST ファイルなので，以下の意見は， JOIS一IIすなわち JICST ファイルに関するもの である)。

\section{1 一次検索機能}

この点については, ニーザの評価はかなり高い。 （意見 1） システム全体の操作性はかなり良好で DIALOG と比べてさほど遜色がない(イ ンデックスファイル検索, トランケー ション, 論理演算, インバーテッドファ イルの通覽, 不要な集合の消去など)。

（意見 2） LOGON 手続きは若干複雑。特に漢字 端末を使う場合，「K」の入れ忘れが頻発 している。特に¥RES 時にこれが多く, もら会話が保存されていないのかとがく 然とすることがある。

（意見 3 ）ちょっと入力を意ると，すぐ切れてし まう。検知時間が少し短か過ぎるのでは ないか。会話型の検索システムの場合は, あらかじめ質問式が100\%固まっていて それを機械的に入力してゆくのではな く, システム側の応答を吟味しながら セッションを進めてゆくところに良さが あるわけで, 現在のように端末の前で少 し考光ていると切断されてしまうという のでは，この良さが十分発揮できない。

（意見 4） システム側の処理が終わるたびに，自 動的にサーチモードに切りかわるので, 一次検索タグ入力の際, コマンド 一DIALOGの SELECTあるいはSの ような一を入力する必要がない点は便利 である。

\section{2 二次検索機能（制限検索）}

この点については, 一次検索以上に高い評価が
与えられている。

（意見 1）この機能はDIALOGになく，しかも いろいろな側面（国，言語……) から可 能なので，実戦的である。

（意見 2）記事区分（CI）による，原著論文，レ ビューなどの分類は大変便利で効果的で ある。

（意見 3 ）二次検索のみでなく, 前方一致の場合 も，そらであるが，ューザはシステム側 の処理にどれくらい時間がかかるのか不 安である。「タイムオーバー」のメッセー ジは, この不安を, 若干なりとも取り除 いてくれる。

\section{3 検索補助機能}

この点では，次のような意見があった。

（意見 1）完全なSEARCH SAVEの機能がな い（現在では, 最後のサーチ・ステート メントのみしか再利用できない。DIALOGのように途中の集合も使用できる ようにならないと，余り効果的でない)。 この点は新旧 JICST ファイルの同時検索がで きない以上，何とか改善してほしいというのが多 くのユーザの意見である。現在 JICST で，このよ らな方向に向けてシステムを改造中とのことであ るので大いに期待がもてる。

（意見 2 ） RESTART (RECONNECT) のやり 方は, DIALOG に比べると, かなり繁雑 である。これは, ログオン・プロシージャ そのものが, 若干ややこしいことに由来 すると思われる。ログオン手続きがもっ と簡略化されれば，¥RESももっと単純 なプロセスとなることが期待される。

公衆回線の伝送品質や入力しないで 放って执くとすぐ切れてしまらというシ ステム側のセンシティブな検知 (3.1 (意 見 3 ）を参照されたい）の状況下では, RESTART 機能の簡略化は重要なポイ ントと思われる。 


\section{4 シソーラス}

オンライン・データベースを検索する場合，き ちんとしたシソーラスがあれば，より効率的な検 索ができることは論をまたない。

特に, JICSTシソーラスの場合, アップポス ティングが自動的になされ，それが JICSTファ イルの入力データ上に反映されているので, 高水 準の再現率を実現する上で都合がよい。最近では 検索前にシソーラスを精査することが習慣化して きている。

（意見 1）分野によっては適切な用語がないケー スがある。この場合，用語の組久合わせ で対処すると, 紋り過ぎて洩れが出るし, 少し広い概念でサーチするとノイズが出 てしまう。

（意見 2 ） シソーラスそれ自体が，必ずしもオン ライン検索 (ないしは機械検索) 用に出 来ているとは，言い難い面がある。例光 ば，第 1 表は，「JICST 科学技術用語シ ソーラスー1981年版」のうち，言い方が 二つあるタームの 1 部である。JOIS の JICST ファイルで, これらの言葉をサー チしよらとすると, 第 1 表の左欄の言葉 をカナで入力しなければならない。

例光ば, IC の場合は,「シュウセキカイ 口」と8 字分になり，「IC」と入れる場合 より 6 字多い。しかも, カナ・シフトキー の操作も必要である。ECの場合は, この 差が12字分にもなる。しかも，これらの 言葉は, もともと英語であり, 右欄のア

第 1 表 JICST シソーラスに拈けるディスクリプタ と非ディスクリプタの例

\begin{tabular}{|c|c|}
\hline ディスクリプタ & 非ディスクリプタ \\
\hline 集 積 回 路 & IC \\
\hline ヨーロッパ共同体 & $\mathrm{EC}$ \\
\hline 品 質 管 理 & QC \\
\hline 線 形 計 画 法 & LP \\
\hline 液 化 天然 ガ ス & LNG \\
\hline 液化石油 ガ ス & LPG \\
\hline ディジタル制御 & $\mathrm{NC}$ \\
\hline
\end{tabular}

クロニムだけでも十分意味が通ずるの で，こちらの方がディスクリプタなら， 検索時の入力の手間はずっと軽減され る。このような例は他にもたくさんある。 ただ事実上は，恐らく印刷体の抄録誌 とのか称合いもあり，オンライン側の都 合だけでディスクリプタを設定するわけ にはゆかないかも知れない。そこで, ディ スクリプタすべてに英数字の短いコード を振って，そちらからも検索できるよう にしてはいかがであろらか。検索時には， いずれにせよ、シソーラスを見るわけだ から，この方法は現実性が高いと思われ る。現に, ニューヨーク・タイムズの 'INFORMATION BANK'やDIALOG の'MANAGEMENT CONTENTS’な どのシソーラスはこの形になっている。

\section{5 出力}

この点については, まずまず満足のようで, 次 のような意見が出ている。

（意見 1）日本語（漢字仮名混じり）の抄録は読 又やすく，抄録の内容構成も妥当。

（意見 2) 出力項目が自由に選べる点はDIALOGより便利。

（意見 3 ） 5 件出力するたびに，先を続けるかど らか，いらいち入力して答えなければな らないのは繁雑に感じられることが多 い。このため, 強制的に端末機の前にく ぎ付けにされる。この機能は残しておい てもよいが, 連続出力のオプションを是 非加えていただきたい。当社のように， 50 ６件を 1 度にオンライン出力するこ とが多い場合は，これがないと大変不便 である。JOIS一II の場合は, ブレーク キーが機能するようなので，連続出力し ても問題はなからう。

（意見 4) 出力項目（フィールド）を任意に決め ることができるのは大きなメリットだと 思らが，¥Pの後にすぐ続いてフィール 
ドネーム（回答出力グループコード）を 入れられるよらにすると一層便利だと思

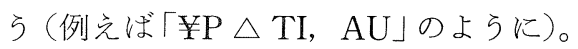

\section{6 一次資料の入手}

JICST ファイルの場合は, オリジナルが原則と して JICSTから入手可能であるので, この面で は，非常に有利である。注文手続きはかなり繁雑 ぞっったが，¥ORDERによりかなり改善された。

（意見 1） $¥ \mathrm{ORD}$ の時のコネクトタイムは無料 にできないか。

（意見 2）コピー料金は，検索料金に比べ割高感 がある。この点はユーザの多くが従来か ら感じているょうである。

\section{7 コスト}

コネクトタイム料金に対しては，評価が分かれ ている。これを妥当とする者も拈り，例光ば DIALOGのNTIS ファイルが外国までつない で, 1 分間250円程度なのと比べると高い感じがす ると述べている者もいる。また，CPUタイムでの 課金の方がよいと主張する者もいるが，これは， どちらかといらと検索経験が浅く, 通常の TSS による計算センター利用に慣れている者に多い意 見である。

\section{8 まめ}

以上の評価を総合すると, ほぼ以下の点に集約 されよう。

（1）一次検索機能は，まずまず満足すべき水準 にある。

（2）二次検索機能は, 非常にユニークなもので, 実用性が極めて高い。

(3) LOGON, RESTARTの手続きはもら少し 簡略化されることが望ましい。
(4) SEARCH SAVE は，登録したサーチ・ス テートメントをすべて再利用できるように改善 すべきである。

(5) ユーザの入力に対するシステム側の検知時 間が短かすぎる。

(6) シソーラスによるアップポスティングが自 動的になされ，下位概念を含むドキュメントも 自動的に拾ってくる点は便利である。

（7）シソーラス自体は，オンライン検索での利 用も考光た構成にすべきである。

(8) 日本語抄録のオンライン出力は大変有効で JOIS をユーザにとってファミリアなものにす る点でも役立っている。

（9） JICST ファイルの場合，一次資料が簡単に 入手できる点は便利だが，コピーの料金や納品 速度の面で一層の改善を望みたい。

(10) オンラインの課金については，今後もコネ クトタイム制でよいと思われるが，料金面では 海外競合システムに対する競争力の観点から， 十分ご配慮いただきたい。

このように全体としては，かなり高い評価が与 えられているが，個々の点についてみると，不満 を述べている者もある。中には，䛊解から生じた 間違った指摘もあるかも知れない。われわれとし ては，こういらユーザの意見を参考にして，JOIS 一IIを少しずつよりよいものにしてゆかれるよう 切望する。また，ユーザに対するこらいった技術 的な面でのアンケートをJICST 側でも実施され てはいかがであろらか。

\section{参考文献}

1) 山崎久道 : オンライン情報検索の利用と情報部門 の役割一三菱総合研究所の場合一 京浜文化22 [2] 17-19 ('81) 